\title{
Nitrogen application improved the growth and yield performance of sweetpotato (Ipomoea batatas (L.) Lam.)
}

\author{
Flore-Anne C. Relente and Luz G. Asio ${ }^{1 *}$
}

\begin{abstract}
Submitted: 14 January 2020 | Accepted: 16 April 2020

Nitrogen is one of the most critical nutrients affecting sweetpotato yield. This study was conducted to 1) evaluate the growth and yield response of sweetpotato NSIC SP 33 to different levels of N; and 2) determine the relationship between N level and root yield. A screenhouse experiment laid out in Completely Randomized Design (CRD) was carried out using five (5) N levels: 0, 40, 80, 120 and $160 \mathrm{~kg} \mathrm{ha}^{-1}$, each replicated thrice. The total amount of $\mathrm{N}$ (as urea) was applied twice, one-half at planting and the other half at six weeks after planting (6 WAP) along with a blanket application of solophos and muriate of potash at 40 and $60 \mathrm{~kg} \mathrm{ha}^{-1} \mathrm{P}_{2} \mathrm{O}_{5}$ and $\mathrm{K}_{2} \mathrm{O}$. An alluvial Umingan sandy loam soil (Inceptisol) was used as medium.

Levels of $\mathrm{N}$ significantly increased the leaf area, fresh herbage, total root yield, biomass, dry matter yield, shoot-root ratio, weight and number of marketable roots. Harvest index ( $\mathrm{HI})$ of plants applied with 40 and $80 \mathrm{~kg} \mathrm{~N} \mathrm{ha}^{-1}$ were comparable to those applied with $0 \mathrm{~N}$. Increasing levels of $\mathrm{N}$ from 0 to $160 \mathrm{~kg} \mathrm{ha}^{-1}$ resulted in higher total crude protein (CP) and total $\mathrm{N}$ in the leaves. $\mathrm{N}$ uptake was higher in $\mathrm{N}$-applied plants. Application of 40 and $80 \mathrm{~kg} \mathrm{ha}^{-1} \mathrm{~N}$ produced the highest root yield, above which root yield declined. Relationship between $\mathrm{N}$ level and root yield developed through regression analysis showed a quadratic function of $Y=111.1794+1.2098 x$ $0.00897 x^{2}$ and R-square of 0.9904 which suggest that inherent soil $N$ affected root development.
\end{abstract}

Keywords: regression analysis, quadratic function, storage roots, $\mathrm{N}$ fertilization, sweetpotato

\section{INTRODUCTION}

Sweetpotato (Ipomoea batatas (L.) Lam.) is a perennial crop of the Convolvulaceae family widely grown as nutritious staple, animal feed and industrial

'Department of Agronomy, Visayas State University, Baybay City, Leyte

*Corresponding Author. Address: Department of Agronomy, Visayas State University, Baybay City, Leyte; Email:luz.asio@vsu.edu.ph

DOI: 10.32945/atr4214.2020submitted: 13 March 2019 | Accepted: 12 November 2019

DOI: 
crop (Woolfe 1992, O'Sullivan et al 1997, Pardales \& Roa 2002, Lebot 2009). In the Philippines, the crop provides livelihood and food security among the resource-poor and vulnerable subsistent people in fragile upland environment (Pardales \& Roa 2002 , Roa et al 2008). It plays supplementary roles to cassava and maize as seasonal source of food and cash crop (Scott et al 2001, Roa et al 2008). Thus, it can help alleviate problems of malnutrition and food insecurity with the use of limited agricultural technologies (Bovell-Benjamin 2007, Mukhopadhyay et al 2011). Sweetpotato can also minimize soil erosion by serving as a good cover crop (Villamayor et al 2017). It can also withstand strong winds making it a climateresilient crop ideal for typhoon-prone areas in the Philippines like Bicol, Leyte and Samar islands among others.

Nitrogen has a strong influence on the distribution of dry matter thus affecting the root and top growth of sweetpotato (O'Sullivan et al 1997, Lebot 2009). N deficiency can cause reduction in growth which is sometimes unrecognizable in the field. This is why adequate $\mathrm{N}$ application improves the vegetative and reproductive growth of the crop. The amount of $\mathrm{N}$ required by the sweetpotato is high and the crop responds positively to $\mathrm{N}$ application whether from organic or inorganic sources (O'Sullivan et al 1997, Essilfie 2015). Ankumah et al (2003) confirmed that $\mathrm{N}$ is an important determinant of yield, however, higher amounts of $\mathrm{N}$ reduce sweetpotato yields (Bourke 1985, Hartemink 2003, Lebot 2009). The pattern is for low rates of $\mathrm{N}$ to increase yield up to some extent, but higher rates could cause root yield to decline (O'Sullivan et al 1997). There have also been studies showing that application of $\mathrm{N}$ increased root yield of sweetpotato, however, high $\mathrm{N}$ levels encouraged vine growth rather than root development (Nedunchezhiyan et al 2012). Excessive vine growth and poor root yield were observed with high amount of $\mathrm{N}$ application (Lebot 2009, Nedunchezhiyan et al 2012). Increasing the $\mathrm{N}$ levels from $30 \mathrm{~kg} \mathrm{ha}^{-1}$ to 60 or $90 \mathrm{~kg} \mathrm{ha}^{-1}$ resulted in reduced root yield (Essilfie 2015). Hartemink et al (2000) also found that root yield of sweetpotato was highest at $100 \mathrm{~kg} \mathrm{ha}^{-1} \mathrm{~N}$ and lowest at $400 \mathrm{~kg} \mathrm{ha}^{-1} \mathrm{~N}$. Until now only limited studies have been done on the response of sweetpotato to $\mathrm{N}$ application in the Philippines thus, this study was conducted.

\section{MATERIALS AND METHODS}

This pot experiment was conducted inside the screenhouse of the Department of Agronomy, VSU, Baybay City, Leyte. Bulk soil surface samples (0-20 cm depth) of an alluvial soil (Inceptisol) were collected, air-dried and sieved using $4 \mathrm{~mm}$ wire mesh before potting. The soil had a near-neutral pH (soil: water, $1: 2.5)$ of $6-6.5$, very low organic matter of $1.29-1.51 \%$, very low total $\mathrm{N}$ of $0.05-0.09 \%$, very low available $P$ of $5.0 \mathrm{mg}$ per $\mathrm{kg}$ but sufficient exchangeable $\mathrm{K}$ of $0.4-0.6 \mathrm{me}$ per $100 \mathrm{~g}$ soil (Landon 1991). Sixty (60) black polyethylene bags (10x10x12in) were filled with ten (10)kg of air-dried and sieved soil. Pots were saturated with tap water and excess was allowed to drain prior to planting.

\section{Fertilizer Application}

A blanket recommended fertilizer rate of 40 and $90 \mathrm{~kg} \mathrm{ha}^{-1} \mathrm{P}_{2} \mathrm{O}_{5}$ and $\mathrm{K}_{2} \mathrm{O}$ (Asio 2018) based on the plant population of 53,333 per hectare was applied using single 
Nitrogen application improved sweetpotato performance

fertilizers solophos (0-18-0) and muriate of potash (0-0-60) applied at planting. Split application of urea (46-0-0) was done to satisfy the different $\mathrm{N}$-treatments: $0 \mathrm{~N}$; $40 \mathrm{~kg} \mathrm{~N} \mathrm{ha}^{-1} ; 80 \mathrm{~kg} \mathrm{~N} \mathrm{ha}^{-1} ; 120 \mathrm{~kg} \mathrm{~N} \mathrm{ha}^{-1}$; and $160 \mathrm{~kg} \mathrm{~N} \mathrm{ha}^{-1}$. First application was done in band $5 \mathrm{~cm}$ deep at planting and the second as side dressing six (6) weeks after planting (WAP).

\section{Planting of Sweetpotato}

Pre-germination of 3-node apical cuttings of sweetpotato var NSIC SP $33(20 \mathrm{~cm}$ long) was done prior to planting. One pre-germinated cutting was planted in a slanting position in each pot for better development of roots (Nedunchezhiyan et al 2012, Asio 2018). Regular watering and hand weeding were done. Few plants were attacked by Erwinia chrysanthemi which caused bacterial stem rot but damage was minimized by application of chlorine solution (Thind et al 1984).

\section{Experimental Design and Statistical Analysis}

The pot experiment was laid out in Completely Randomized Design (CRD) in a screenhouse with five (5) treatments, three (3) replications per treatment and four (4) plants per replication. Data were analyzed using Analysis of Variance (ANOVA) using Statistical Analysis Software (SAS) version 6.12. Comparison of treatments were done using Tukey's Honest Significant Difference (HSD) test. Regression analysis was performed to determine the relationship between the levels of $\mathrm{N}$ and root yield.

\section{Harvesting and Grading of Roots}

Storage roots were harvested 98 days after planting by manually digging them out of the soil after cutting the vines. All harvested roots were cleaned and sorted into marketable and non-marketable roots. Roots that were considered marketable were at least $2.5 \mathrm{~cm}$ in diameter (broadest part) and $6.5 \mathrm{~cm}$ in length (proximal to distal end). Roots damaged by pests and diseases were not included.

\section{Laboratory Analysis}

Twenty (20) healthy mature leaves of sweetpotato were randomly collected at harvest from each treatment per replication. The leaves were washed with distilled water and oven-dried at $70^{\circ} \mathrm{C}$ until constant weight. The dried leaves were ground using a Wiley mill and sieved $(250 \mu \mathrm{m})$. Powdered samples were analyzed for total $\mathrm{N}$ (Micro-Kjeldahl method, Westerman 1990), total crude protein (result of total N x 6.25 CF, FAO \& WHO 2019), and N uptake (dry matter yield of biomass $x$ total N).

A composite soil sample $(500 \mathrm{~g})$ was air-dried, pulverized and analyzed for soil $\mathrm{pH}$ (soil: water ratio of 1:2.5; Kalra 1995), total organic carbon (Walkley Black Method 1934), total N (Micro-Kjeldahl method by Jackson 1958), available P (Bray \& Kurtz 1945), and exchangeable K (Ammonium Acetate buffered to $\mathrm{pH}$ 7.0) read using AAS (Jones 2001). 


\section{Data Gathered}

Growth characteristics such as main vine length, number of lateral vines and leaf area $\left(\mathrm{cm}^{2}\right)$ were taken at harvest. Leaf area was estimated using the formula:

Leaf Area $=$ Length $\mathrm{x}$ Width $\mathrm{x}$ Correction Factor for NSIC SP 33

where: Correction Factor $=0.554$

For the yield and yield components of sweetpotato such as number and weight of marketable and non-marketable roots, fresh herbage weight, total root yield, dry matter yield and shoot to root ratio were measured at harvest. Shoot-to-root ratio was computed using the formula:

$$
\text { Shoot root }=\frac{\text { Dry weight }(\mathrm{g}) \text { of shoots }}{\text { Dry weight }(\mathrm{g}) \text { of roots }}
$$

\section{Harvest Index (HI)}

$\mathrm{HI}$ is the ratio of the fresh weight of roots (economic yield) to the fresh weight of roots + herbage yield (biological yield). It emphasizes allocation of carbon to production of roots. A higher $\mathrm{HI}$ means that photosynthates are allocated more in the production of roots while a low $\mathrm{HI}$ means more photosynthates are translocated to vegetative parts of the plant. HI was computed using the formula:

$$
\mathrm{HI}=\frac{\text { Economic Yield }(\text { root yield })}{\text { Biological Yield }(\text { herbage }+ \text { root yield })}
$$

\section{RESULTS AND DISCUSSION}

The effects of the different $\mathrm{N}$ levels became more evident as the plants grew and matured. Sweetpotato plants with no $\mathrm{N}$ application (control plants) showed stunted growth and yellowing of most of the leaves while the $\mathrm{N}$-applied ones developed large green leaves and more vines. Plants fertilized with $\mathrm{N}$ produced more lateral vines and longer main vines than those with no $\mathrm{N}$. $\mathrm{N}$ application increased vine growth and produced more leaves, but higher $\mathrm{N}$ doses resulted in excessive growth (Lebot 2009, Nedunchezhiyan et al 2012).

\section{Growth Characteristics}

Application of $120 \mathrm{~kg} \mathrm{ha}^{-1} \mathrm{~N}$ produced the largest leaf area but was not significantly different from those applied with $80 \mathrm{~kg} \mathrm{ha}^{-1} \mathrm{~N}$ and $160 \mathrm{~kg} \mathrm{ha}^{-1} \mathrm{~N}$ (Table 1). Plants with no $\mathrm{N}$ application produced the smallest leaves. Marschner (1995) stated that when $\mathrm{N}$ is less than the optimum during leaf development of plants, leaf area is affected due to insufficient cell expansion. Plants suffering from low $\mathrm{N}$ supply $(0 \mathrm{~N})$ have low leaf elongation rates due to reduced number and duration of epidermal cell extension. $\mathrm{N}$ deficiency plays a key role in leaf senescence resulting in the termination of root growth (Marschner 1995). 
Nitrogen application improved sweetpotato performance

Table 1. Growth characteristics of sweetpotato (Ipomoea batatas (L.) Lam.) var NSIC SP 33 as affected by levels of $\mathrm{N}$

\begin{tabular}{lccc}
\hline Treatments & $\begin{array}{c}\text { Length of Main Vines } \\
(\mathrm{cm})\end{array}$ & $\begin{array}{c}\text { Number of Primary } \\
\text { Lateral Vines }\end{array}$ & $\begin{array}{c}\text { Leaf Area } \\
\left(\mathrm{cm}^{2}\right)\end{array}$ \\
\hline $0 \mathrm{~N}$ & 245.83 & 2.75 & $16.12^{\mathrm{d}}$ \\
$40 \mathrm{~kg} \mathrm{~N} \mathrm{ha}^{-1}$ & 221.75 & 3.08 & $27.75^{\mathrm{c}}$ \\
$80 \mathrm{~kg} \mathrm{~N} \mathrm{ha}^{-1}$ & 283.00 & 3.58 & $28.57^{\mathrm{bc}}$ \\
$120 \mathrm{~kg} \mathrm{~N} \mathrm{ha}^{-1}$ & 306.75 & 3.25 & $30.92^{\mathrm{a}}$ \\
$160 \mathrm{~kg} \mathrm{~N} \mathrm{ha}^{-1}$ & 274.17 & 3.50 & $29.69^{\mathrm{ab}}$ \\
\hline Mean & 266.30 & 3.23 & 26.61 \\
\hline $\mathrm{cv}(\%)$ & 10.66 & 3.23 & 3.60 \\
\hline
\end{tabular}

Treatment means within a column having no letter or having a common letter(s) are not significantly different at $5 \%$ level of significance using Tukey's test.

\section{Yield and Yield Components}

Plants applied with $80 \mathrm{~kg} \mathrm{ha}^{-1} \mathrm{~N}$ produced more and heavier marketable roots, higher total root and dry matter yield compared to other treatments except for those plants applied with $40 \mathrm{~kg} \mathrm{ha}^{-1} \mathrm{~N}$ and $120 \mathrm{~kg} \mathrm{ha}^{-1} \mathrm{~N}$ (Table $2 \& 3$ ). Higher total biomass and shoot-to-root ratio were observed in plants applied with $120 \mathrm{~kg} \mathrm{ha}^{-1} \mathrm{~N}$ but were not significantly different from those with $80 \mathrm{~kg} \mathrm{ha}^{-1} \mathrm{~N}$ and $160 \mathrm{~kg} \mathrm{ha}^{-1} \mathrm{~N}$. Generally, plants applied with $\mathrm{N}$ were superior to plants without $\mathrm{N}$ application (control plants). The effect of mineral nutrient supply on the yield response of crops often reflects sink limitations imposed by either a deficiency or an excessive supply during certain critical periods of crop growth (Marschner 1995). In root and tuber crops as is the case with sweetpotato, sink competition between vegetative growth and production of roots often manifests. In this study, total root yield increased with the application of 80 to $120 \mathrm{~kg} \mathrm{ha}^{-1} \mathrm{~N}$ and declined beyond this rate (Table 3). Similar results were obtained by Sebastiani et al (2006) that further increase in N rate reduced the root yield while a continuous supply of $\mathrm{N}$ to the roots either prevented or delayed root development and enhanced vegetative growth (Krauss \& Marschner 1971). Herbage yield was also observed to increase as rates of $N$ were increased from 0 to $160 \mathrm{~kg} \mathrm{ha}^{-1}$.

$\mathrm{N}$ fertilization significantly influenced the harvest index of sweetpotato. $\mathrm{HI}$ of control plants $(0 \mathrm{~N})$ were comparable to those applied with $40 \mathrm{~kg} \mathrm{ha}^{-1} \mathrm{~N}$ and $80 \mathrm{~kg} \mathrm{ha}^{-1}$ $\mathrm{N}$ (Table 2). Lowest $\mathrm{HI}$ was obtained in plants applied with $160 \mathrm{~kg} \mathrm{ha}{ }^{1} \mathrm{~N}$. Nitrogen has a strong influence on the distribution of dry matter (Lebot 2009). Increasing N rates encourage vegetative growth rather than root development (Nedunchezhiyan et al 2012). The low $\mathrm{HI}$ in plants applied with $160 \mathrm{~kg} \mathrm{~N}^{-1}$ means that photosynthates produced were allocated more to the vegetative parts rather than to the roots. Higher levels of $\mathrm{N}$ could sometimes depress root development resulting to reduced root yield of sweetpotato (Hartemink 2003). 
Table 2. Yield and yield components of sweetpotato (Ipomoea batatas (L.) Lam.) var NSIC SP 33 as affected by levels of $\mathrm{N}$

\begin{tabular}{|c|c|c|c|c|c|}
\hline \multirow[b]{2}{*}{ Treatments } & \multicolumn{2}{|c|}{ Number of roots/plant } & \multicolumn{2}{|c|}{ Weight (g) of roots/plant } & \multirow{2}{*}{$\begin{array}{c}\text { Harvest } \\
\text { Index }\end{array}$} \\
\hline & Marketable & $\begin{array}{c}\text { Non- } \\
\text { marketable }\end{array}$ & Marketable & $\begin{array}{c}\text { Non- } \\
\text { marketable }\end{array}$ & \\
\hline $0 \mathrm{~N}$ & $1.33^{\mathrm{bc}}$ & 1.33 & $92.92^{b c}$ & 20.25 & $0.64^{\mathrm{a}}$ \\
\hline $40 \mathrm{~kg} \mathrm{~N} \mathrm{ha}^{-1}$ & $2.00^{\mathrm{ab}}$ & 0.67 & $128.08^{a}$ & 12.42 & $0.56^{\mathrm{ab}}$ \\
\hline $80 \mathrm{~kg} \mathrm{~N} \mathrm{ha}^{-1}$ & $2.67^{a}$ & 1 & $141.58^{\mathrm{a}}$ & 11.25 & $0.58^{\mathrm{ab}}$ \\
\hline $120 \mathrm{~kg} \mathrm{~N} \mathrm{ha}^{-1}$ & $1.67^{\mathrm{bc}}$ & 1.33 & $118.17^{\mathrm{ab}}$ & 10.83 & $0.44^{\mathrm{bc}}$ \\
\hline $160 \mathrm{~kg} \mathrm{~N} \mathrm{ha}^{-1}$ & $1.00^{c}$ & 1 & $66.33^{c}$ & 7.67 & $0.35^{\mathrm{c}}$ \\
\hline Mean & 1.73 & 1.07 & 109.42 & 12.48 & 0.51 \\
\hline $\mathrm{cV}(\%)$ & 25.8 & 59.29 & 9.29 & 55.62 & 10.56 \\
\hline
\end{tabular}

Treatment means within a column without letter or having a common letter(s) are not significantly different at $5 \%$ level of significance using Tukey's test

Table 3. Yield and yield components of sweetpotato (Ipomoea batatas (L.) Lam.) var NSIC SP 33 as affected by levels of $\mathrm{N}$

\begin{tabular}{lcccccc}
\hline Treatments & $\begin{array}{c}\text { Fresh } \\
\text { Herbage } \\
(\mathrm{g} / \text { plant })\end{array}$ & $\begin{array}{c}\text { Total Root } \\
\text { Yield } \\
(\mathrm{g} / \text { plant })\end{array}$ & $\begin{array}{c}\text { Total Root } \\
\text { Yield } \\
\left(\mathrm{t} \text { ha } \mathrm{a}^{-1}\right)\end{array}$ & $\begin{array}{c}\text { Total } \\
\text { Biomass } \\
(\mathrm{g} / \text { plant })\end{array}$ & $\begin{array}{c}\text { Dry Matter } \\
\text { Yield } \\
(\mathrm{g} / \text { plant })\end{array}$ & $\begin{array}{c}\text { Shoot: root } \\
\text { Ratio }\end{array}$ \\
\hline $0 \mathrm{~N}$ & $63.58^{\mathrm{c}}$ & $113.17^{\mathrm{b}}$ & $6.04^{\mathrm{b}}$ & $176.75^{\mathrm{d}}$ & $38.75^{\mathrm{bc}}$ & $0.43^{\mathrm{b}}$ \\
$40 \mathrm{~kg} \mathrm{~N} \mathrm{ha}^{-1}$ & $113.67^{\mathrm{ab}}$ & $140.50^{\mathrm{a}}$ & $7.49^{\mathrm{a}}$ & $254.17^{\mathrm{b}}$ & $44.08^{\mathrm{ab}}$ & $0.75^{\mathrm{ab}}$ \\
$80 \mathrm{~kg} \mathrm{~N} \mathrm{ha}^{-1}$ & $112.75^{\mathrm{b}}$ & $152.83^{\mathrm{a}}$ & $8.15^{\mathrm{a}}$ & $265.58^{\mathrm{ab}}$ & $47.67^{\mathrm{a}}$ & $0.64^{\mathrm{ab}}$ \\
$120 \mathrm{~kg} \mathrm{~N} \mathrm{ha}^{-1}$ & $161.67^{\mathrm{a}}$ & $129.00^{\mathrm{ab}}$ & $6.88^{\mathrm{ab}}$ & $290.67^{\mathrm{a}}$ & $45.33^{\mathrm{a}}$ & $1.52^{\mathrm{a}}$ \\
$160 \mathrm{~kg} \mathrm{~N} \mathrm{ha}^{-1}$ & $138.25^{\mathrm{ab}}$ & $74.00^{\mathrm{c}}$ & $3.95^{\mathrm{c}}$ & $212.25^{\mathrm{a}}$ & $35.63^{\mathrm{c}}$ & $1.46^{\mathrm{ab}}$ \\
\hline Mean & 117.98 & 121.9 & 6.502 & 239.88 & 42.29 & 0.96 \\
\hline $\mathrm{cv}(\%)$ & 15.35 & 7.37 & 8.17 & 4.69 & 8.14 & 41.64
\end{tabular}

Treatment means within a column without letter or having a common letter(s) are not significantly different at $5 \%$ level of significance using Tukey's test

\section{Nitrogen Uptake and Total CP Contents of Sweetpotato}

Plants applied with $\mathrm{N}$ had total $\mathrm{N}$ contents above the critical concentration of $2.0 \%$ while plants with no $\mathrm{N}$ application $(0 \mathrm{~N})$ showed $\mathrm{N}$ content which were below the critical limit (Marschner 1995) (Table 4). The study showed that application of $N$ significantly increased the $\mathrm{N}$ uptake of the sweetpotato plants. Higher $\mathrm{N}$ uptake was observed in plants applied with high amounts of $\mathrm{N}$ which ranged from 138.64 to 162.27g per plant. 
Nitrogen application improved sweetpotato performance

Total crude protein refers to the approximate amount of protein in foods estimated from total $\mathrm{N}$ content determined by Kjeldahl analysis (Simmone et al 1996). Although not significantly influenced by $\mathrm{N}$ fertilization, total crude protein in the leaves of sweetpotato increased with increasing levels of $\mathrm{N}$. According to Walter et al (1984), total crude protein in sweetpotato ranges from $15-35 \%$.

Table 4. Total N, N uptake and total CP of sweetpotato (Ipomoea batatas (L.) Lam.) var NSIC SP 33 as affected by levels of $\mathrm{N}$

\begin{tabular}{lccc}
\hline Treatments & $\begin{array}{c}\text { Total N } \\
(\%)\end{array}$ & Total Crude Protein (\%) & $\begin{array}{c}\text { Nitrogen } \\
\text { Uptake (g/pot) }\end{array}$ \\
\hline $0 \mathrm{~N}$ & 1.967 & 12.29 & $76.22^{\mathrm{b}}$ \\
$40 \mathrm{~kg} \mathrm{~N} \mathrm{ha}^{-1}$ & 3.145 & 19.66 & $138.64^{\mathrm{a}}$ \\
$80 \mathrm{~kg} \mathrm{~N} \mathrm{ha}^{-1}$ & 3.284 & 20.53 & $156.54^{\mathrm{a}}$ \\
$120 \mathrm{~kg} \mathrm{~N} \mathrm{ha}^{-1}$ & 3.393 & 21.21 & $153.82^{\mathrm{a}}$ \\
$160 \mathrm{~kg} \mathrm{~N}^{-1}$ & 4.554 & 28.46 & $162.27^{\mathrm{a}}$ \\
\hline $\begin{array}{l}\text { Treatment means within a column without letter or having a common letter (s) are not significantly different at } 5 \% \text { level of } \\
\text { significance using Tukey's test. }\end{array}$
\end{tabular}

\section{Yield Response of Sweetpotato to N Fertilization}

Increasing the levels of $\mathrm{N}$ from 0 to $80 \mathrm{~kg} \mathrm{ha}^{-1} \mathrm{~N}$ also increased the root yield from $113 \mathrm{~g}$ to $152.83 \mathrm{~g} \mathrm{plant}^{-1}$ (Figure 1). However, further increase in the rate of $\mathrm{N}$ to $160 \mathrm{~kg}$ ha' resulted in the decline of the sweetpotato root yield. $\mathrm{N}$ supply has strong influence on the dry matter distribution of sweetpotato thus, affecting the root yield relative to its top growth (O' Sullivan et al 1997). When $\mathrm{N}$ supply is high, it may cause luxuriant growth of vines and leaves most often resulting in reduced root yield. High amounts of $\mathrm{N}$ encourage vine growth rather than root development (Nedunchezhiyan et al 2012).

A quadratic function can be described by an equation of the form $f(x)=a x^{2}+b x+c$, where $a$ is the coefficient of $x^{2}, b$ is the coefficient of $x$, and $c$ is the term without any $x$ or is the constant (Khan Academy 2019). The graph of the quadratic function is a curve called parabola which either opens upward or downward and vary in width or steepness. Results showed that the yield response of sweetpotato to $\mathrm{N}$ application determined by regression analysis can be described by a quadratic function of $Y=111.1794+1.2098 x-0.00897 x^{2}$ with $R^{2}=0.9904$ where $x$ is the levels of $N$. The equation reveals that root yield of $111.1794 \mathrm{~g} \mathrm{plant}^{-1}$ was obtained with $0 \mathrm{~N}$ application. This means that the inherent $\mathrm{N}$ in the soil produced $111 \mathrm{~g}$ plant ${ }^{-1}$ root yield. The $\mathrm{R}^{2}$ in the figure refers to the coefficient of determination which measures the percentage variation of the dependent variable (root yield) due to the independent variable ( $\mathrm{N}$ levels). It is always between 0 and 1 ; 00 value indicates that the model explains none of the variability of the response data around its mean while a value of 1 indicates that the model explains all the variability of the response data around its mean. Figure 1 shows that the yield response of sweetpotato 
is largely due to the different $\mathrm{N}$ levels applied as indicated by the high $\mathrm{R}^{2}$ value $(=0.9904)$. The same result was also reported by Asio et al (2018).

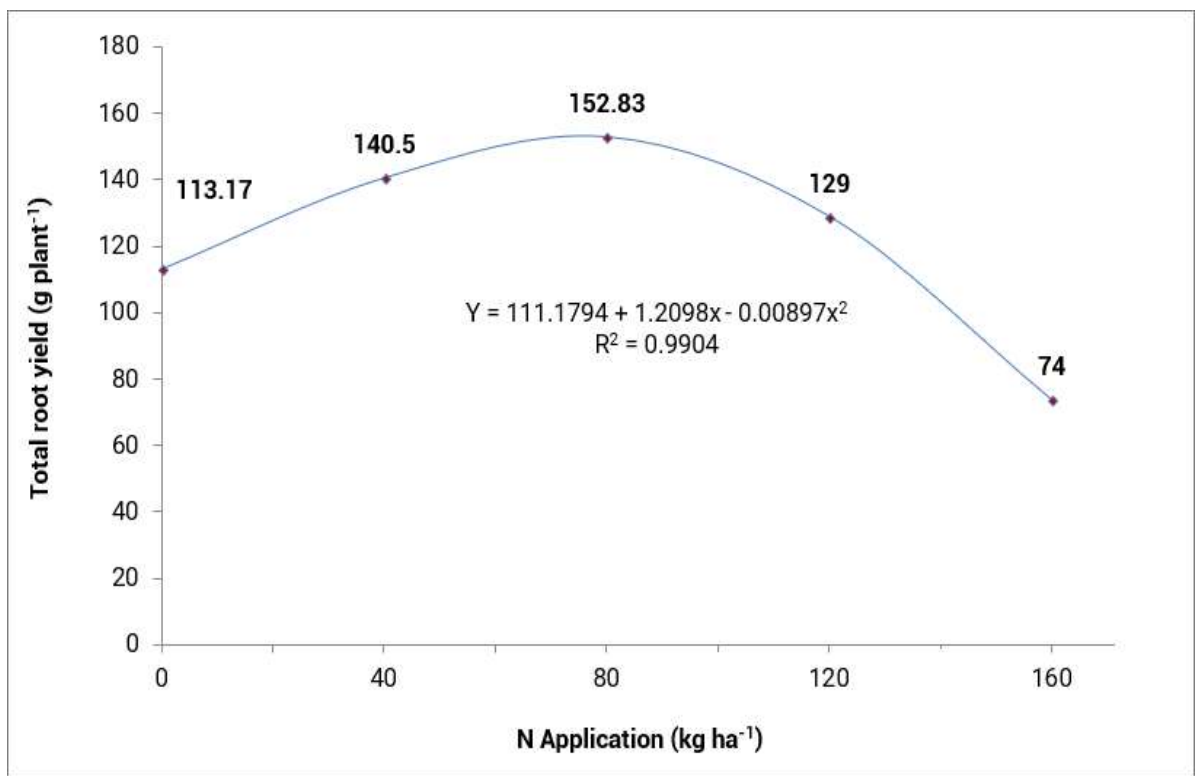

Figure 1. Yield response of sweetpotato (Ipomoea batatas (L.) Lam.) var SP 33 as affected by levels of $\mathrm{N}$

\section{CONCLUSION}

Different levels of $\mathrm{N}$ significantly increased the leaf area, fresh herbage yield, total root yield, total biomass, dry matter yield, shoot-to-root ratio as well as number and weight of sweetpotato marketable roots. Harvest index of sweetpotato was the same in plants without $\mathrm{N}$ application and those that received 40 and $80 \mathrm{~kg} \mathrm{ha}^{-1} \mathrm{~N}$. Increasing levels of $\mathrm{N}$ resulted in increased total crude protein and total $\mathrm{N}$ in the leaves. N uptake was highest in plants applied with N. Application of 40 and $80 \mathrm{~kg} \mathrm{ha}^{-1}$ $\mathrm{N}$ produced the highest root yield but increasing it further to $160 \mathrm{~kg} \mathrm{ha}^{-1} \mathrm{~N}$ resulted in the decline of the root yield. The relationship between $\mathrm{N}$ levels applied and root yield developed through regression analysis showed a quadratic function of $Y=111.1794+1.2098 x-0.00897 x^{2}$ with an $R^{2}$ value of 0.9904 . Inherent $N$ in the soil resulted in the production of $111 \mathrm{~g}$ of roots per plant. Based on this quadratic function developed, the application of $80 \mathrm{~kg} \mathrm{ha}^{-1} \mathrm{~N}$ for sweetpotato var NSIC SP 33 is recommended. 
Nitrogen application improved sweetpotato performance

\section{REFERENCES}

Ankumah RO, Khan V, Mwamba K \& Kpomblekou-A K. 2003. The influence of source and timing of nitrogen fertilizers on yield and nitrogen use efficiency of four sweet potato cultivars. Agriculture, Ecosystems and Environment 100(23):201-207

Asio LG. 2018. Growth response function, mineral nutrition and quality of sweetpotato (Ipomoea batatas (L.) Lam.) var Siete Flores in Relation to fertilization (PhD dissertation). CLSU, Science City of Munoz, Nueva Ecija

Asio LG, Tamayo NV \& Dela Cruz NE. 2018. Response of traditional sweetpotato (Ipomoea batatas (L.) Lam. variety to fertilization in Leyte, Philippines. Tropentag 2018: International Conference on Research on Food Security, Natural Resource Management and Rural Development, Ghent University, Belgium, on Sept 17-19, 2018

Bourke RM. 1985. Sweetpotato (Ipomoea batatas) production and research in Papua New Guinea. Papua New Guinea Journal of Agriculture, Forestry and Fisheries 33(3-4):89-108

Bovell-Benjamin AC. 2007. Sweet Potato: A Review of Its Past, Present, and Future Role in Human Nutrition. Advances in Food and Nutrition Research 52:1-59

Bray RH and Kurtz LT.1945. Determination of total organic and available forms of phosphorus in Soils. Soil Science 59(1):39-45

Essilfie MS. 2015.Yield and storability of sweetpotato (Ipomoea batatas (L.) as influenced by chicken manure and inorganic fertilizer (PhD dissertation). University of Ghana, Lego

Food and Agriculture Organization of the United Nations and World Health Organization (FAO \& WHO). 2019. Nitrogen and protein content measurement and nitrogen to protein conversion factors for dairy and soy protein-based foods: a systematic review and modelling analysis. Prepared by Daniel Tomé, Christophe Cordella, Omar Dib, Christine Péron. http://www.fao.org/fao-whocodexalimentarius

Hartemink AE, Johnson M, O'Sullivan JN \& Oloma S. 2000. Nitrogen use efficiency of taro and sweetpotato in the humid lowlands of Papua New Guinea. Agriculture, Ecosystems and Environment 79(2-3):271-280

Hartemink AE. 2003. Integrated nutrient management research with sweet potato in Papua New Guinea. Outlook on Agriculture 32(3):173-182

Jones JB Jr. 2001. Laboratory Guide for Conducting Soil Tests and Plant Analysis. CRC Press, Boca Raton

Jackson ML.1958. Soil Chemical Analysis. Prentice-Hall, Inc., Englewood Cliffs, NJ

Kalra YP.1995. Determination of $\mathrm{pH}$ of soils by different methods: Collaborative Study. Journal of AOAC International 78:310-321

Khan Academy. Accessed November 6, 2019. https://www.khanacademy.org

Krauss A and Marschner H. 1971. Influence of direct supply of calcium to potato tubers on the yield and calcium content. Zeitschrift fur Pflanzenernahrung Bodenkunde 129(1):1-9

Landon JR.1991. Booker Tropical Soil Manual. A Handbook for Soil Survey and Agricultural Land Evaluation in the Tropics and sub Tropics. Longman Scientific and Technical Publisher, Harlon 
Lebot V. 2009. Tropical Root and Tuber Crops: Cassava, Sweet Potato, Yams and Aroids. Crop production science in horticulture (17), CAB books, CABI, Wallingford, UK. Springer

Marschner H. 1995. Mineral nutrition of higher plants. Annals of Botany 78:527-528

Mukhopadhyay SK, Chattopadhyay A, Chakraborty I \& Bhattacharya I. 2011. Crops that feed the world 5. Sweetpotato. Sweetpotatoes for income and food security. Food Security 3:283-305

Nedunchezhiyan M, Byju G \& Ray RC. 2012. Effect of tillage, irrigation, and nutrient level on growth and yield of sweetpotato in rice fallow. International Scholarly Research Network(ISRN)Agronomy 2012(1):114-126

Nedunchezhiyan M, Byju G \& Jata SK. 2012. Sweet Potato Agronomy. Fruit, Vegetable and Cereal Science and Biotechnology 6 (Special issue 1):1-10. Global Science Books

O'Sullivan JN, Asher CJ \& Blamey FPC. 1997. Nutrient Disorders of Sweet Potato. Australian Center for International Agricultural Research. Canberra ACT 2601, Australia. ACIAR Monograph No. 48

Pardales JR and Roa J. 2002. Rootcrop Agriculture in the Philippines: the quest for food security and livelihood (pp3-12). In: Secondary Farmers of Secondary Crops Women and root crop livelihood in the Philippines. FAO-RAP Project, CIPUPWARD, Los Baños, Laguna, Philippines

Roa J, Kadohira M, Bergantin R, Bolatete DM Jr \& Yamauchi A. 2008. Farmers' decision-making strategies on selecting rootcrop varieties in the Visayas Region, Philippines. Research bulletin of Obihiro University 29:1-12

Sebastiani SK, Mgonja A, Urio F \& Ndondi T. 2006. Response of sweetpotato (Ipomoea batatas) to application of nitrogen and phosphorus fertilizers in the Northern Highlands of Tanzania. ACTA Horticulturae 703:219-224

Simonne AH, Green NR \& Bransby DI. 1996. Consumer acceptability and $\beta$-carotene content of beef as related to cattle finishing diets. Journal Food Science 61(6):1254-1257

Scott GJ, Best R, Rosegrant M \& Bokanga M. 2001. Roots and Tubers in the Global Food System: A Vision Statement to the year 2020. A co-publication of the International Potato Center (CIP), Centro Internacional de Agricultura Tropical (CIAT), International Food Policy Research Institute (IFPRI), International Institute of Tropical Agriculture (IITA), and International Plant Genetic Resources Institute (IPGRI). Printed in Lima, Peru: International Potato Center. www.cipotato.org

Thind BS, RAndhawa PS \& Soni PS. 1984. Chemical control of bacterial stalk rot (Erwinia chrysanthemi pv. zeae) and leaf stripe (Pseudomonas rubrilineans) of maize/Chemische Bekämpfung der bakteriellen Stengelfäule (Erwinia chrysanthemi pv. zeae) und der Blattstreifenkrankheit (Pseudomonas rubilineans). Journal Storage 91(4):424-430.

Villamayor FP, Asio VB, Lerios AO, Asio LG \& Sabijon JR. 2017. Soil erosion in the marginal upland of Inopacan Leyte, Philippines. Annals of Tropical Research 39 (Supplement A):115-124

Walkley AJ and Black IA. 1934. Estimation of soil organic carbon by the chromatic acid titration method. Soil Science 37:29-38

Walter WM Jr, Collins WW \& Purcell AE. 1984. Sweetpotato protein: A Review. Journal of Agricultural and Food Chemistry 32(4):695-699 
Nitrogen application improved sweetpotato performance

Westerman RL. 1990. Soil Testing and Plant Analysis (3rd edn). Soil Science Society of America, Madison, Wisconsin

Woolfe JA. 1992. Sweet potato: An untapped food resource. Cambridge University Press, Cambridge. 